\title{
Research Article \\ Elk (Cervus elaphus) Seasonal Habitat Selection in a Heterogeneous Forest Structure
}

\author{
Jesse N. Popp, ${ }^{1}$ David N. C. McGeachy, ${ }^{1}$ and Josef Hamr ${ }^{2}$ \\ ${ }^{1}$ Laurentian University, 935 Ramsey Lake Road, Sudbury, ON, Canada P3E 2C6 \\ ${ }^{2}$ School of Renewable Energy and Environmental Studies, Cambrian College, 1300 Barrydowne Road Sudbury, ON, Canada P3A 3 V8 \\ Correspondence should be addressed to Jesse N. Popp; jesse_hubley@hotmail.com
}

Received 21 April 2013; Revised 17 June 2013; Accepted 24 June 2013

Academic Editor: Friedrich Reimoser

Copyright (c) 2013 Jesse N. Popp et al. This is an open access article distributed under the Creative Commons Attribution License, which permits unrestricted use, distribution, and reproduction in any medium, provided the original work is properly cited.

\begin{abstract}
Seasonal habitat selection by the reintroduced Burwash elk population, approximately $30 \mathrm{~km}$ south of Sudbury, Ontario, has been analysed in order to assist in the development of future management. Twenty-five adult females were radio-collared and tracked 1-3 times a week for 3 years. The most prominent patterns included selection of intolerant hardwood forests (trembling aspen, white birch, and balsam poplar) during all seasons, while Great Lakes-St. Lawrence pines (white and red pine dominated stands) were used less than expected based on availability for all seasons. The selection patterns are likely associated with seasonal climatic conditions and forage preferences. Because the selection behaviours displayed here varied greatly from other elk habitat studies, it is suggested that managers consider the importance of population-specific habitat studies before developing related strategies.
\end{abstract}

\section{Introduction}

Historically, elk (Cervus elaphus) were distributed across many regions of Canada [1-3]. Due to human competition for land, throughout the 1800s, elk populations across North America were severely depressed and extirpated in some areas [2]. After unsuccessful attempts to reintroduce elk into Ontario in the 1930s and 1940s, more recent (19982001) reintroductions resulted in the successful establishment of elk populations including those introduced to the Burwash region, approximately $30 \mathrm{~km}$ south of Sudbury, Ontario [4-8]. Now considered acclimated to their surroundings in Burwash [9], habitat selection of this population must be assessed in order to assist in management strategies.

Elk habitat selection has been well documented throughout much of the species' Western range in North America [10-16]. Many factors influence elk habitat selection, including food availability and quality, shelter, cover, predator avoidance, temperature, water availability, elevation, slope, and snow conditions [17-19]. Density of conspecifics may also influence selection [20,21]. Habitat use in relation to forest cover and productive foraging habitats has been well studied in elk [22-27]; however, selection of forest cover types in heterogeneous forest structures remains less clear.

Habitat use decisions vary with resource availability, and the knowledge of regional habitat selection is important for wildlife management strategies [28]. Habitat selection by the Burwash elk population has been previously studied; however, many of its aspects are still in need for examination. It has long been accepted that habitat selection is a hierarchical process that may vary with scale [29]. At large scales, elk have shown selection of home ranges based on wolf spatial distribution, whereas at smaller scales, forage is more influential on selection patterns [28]. In the Burwash region, elk did not appear to limit habitat use based on the risk of wolf predation [30], whereas forage played a key role in habitat selection behaviour [31]. Brown [32] and Jost [33] studied habitat selection in a small, remnant Burwash elk population prior to the onset of reintroductions in 1998. Martin [9] looked at annual habitat selection and movement patterns of the reintroduced elk population from 1998 to 2005 to determine when acclimatization had occurred. Kittle et al. [30] related winter habitat selection to wolf predation risk. However, all three studies were plagued by small sample sizes, had conflicting results, and did not examine seasonal differences in selection. 
Elk commonly display variable resource selection patterns in different seasons [15, 34-37]. We studied elk habitat selection in a transitional ecoregion with a heterogeneous forest structure by examining 25 adult female elk in the Burwash region over 3 years. Available resources were based on habitat types as categorized by Ontario Forest Resource Inventory Maps (Table 2).

\section{Methods}

2.1. Study Area. The study area was located in the Great Lakes-St. Lawrence Ecotonal Forest Region [37] which is mainly comprised of mixed conifer-hardwood forests [38]. In the past, glaciations produced flat to rolling topography [39] characterized by rugged outcrops of granite with rounded tops at maximum elevations of $300 \mathrm{~m}$ [33]. The topography also consists of valleys and many water bodies (lakes and streams), as well as wetlands (marshes, swamps, and bogs/fens), typical of the Precambrian Shield.

The Burwash Correctional Facility/Industrial Farm $\left(46^{\circ} 15^{\prime} \mathrm{N}, 80^{\circ} 50^{\prime} \mathrm{W}\right)$ was closed in 1973 [40]. Part of the land was transferred to the Department of National Defence for training purposes in the early 1990s. The property now encompasses more than 14,000 ha of mixed forest, red pine plantations, several lakes, a major river, and approximately 4,000 ha of open, abandoned fields [9, 32] (Figure 1). The climate in this region is continental [41].

2.2. Data Collection and Analysis. Female elk were fitted with Lotek Engineering LMRT 4 VHF radio-collars with motion sensitive mortality sensors and were tracked from the ground or aerially with a Lotek SRX 400 telemetry receiver. A hand-held 2-element $\mathrm{H}$-antenna was used to receive signals. Tracking occurred 1-3 times per week during the day, between the winter 2008 and fall 2011. Only daytime tracking was performed and night habitat use may differ from day use. At least three compass bearings were obtained for each elk location from various high points within the elk population range in order to reduce triangulation error [42]. Triangulation error was calculated from 2 dummy collars placed in habitats, where elk were frequently found. Error was assessed for both leaf-on and leaf-off time periods. There was no significant difference in error between leaf-on and leaf-off periods (paired $t$-test $P<0.05$ ). Accuracy was 170 $( \pm 20.5) \mathrm{m}$ from blind trials $(n=56)$. Individual locations were triangulated on topographic maps and recorded as UTM coordinates (scale 1:50,000, UTM Zone 17T).

Seasons were delineated as 4 segments of 3 months, based on elk behaviour (Table 1). Initially, seasonal habitat analyses were performed separately for each year. Seasonal locations were pooled for all years. Since the Burwash elk population consists of a main larger herd and several smaller satellite groups, it is considered a metapopulation. The telemetry data used for analysis was from females who spent the majority of their time within the main or "core" herd. Data collected for 25 female elk was analyzed for spatial association between individuals using the software Association [43]. To ensure individual movements were independent from each other,

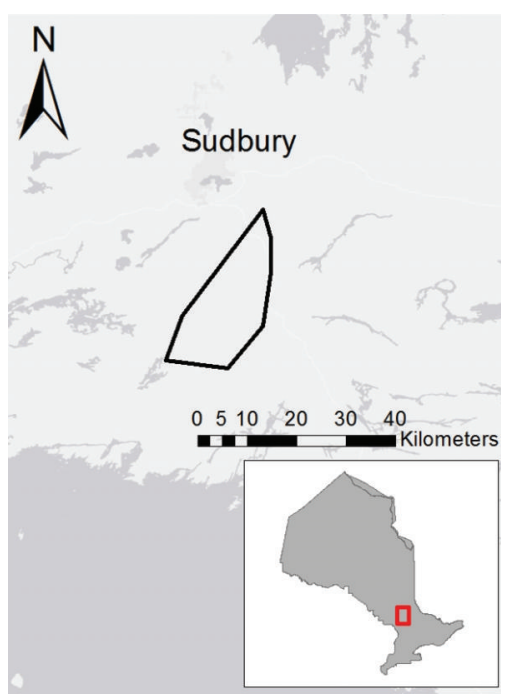

FIGURE 1: The Burwash elk core population range (polygon) created using females that spent the majority of their time within the main herd in the Burwash area of Ontario.

TABLE 1: Seasons based on elk behaviour.

\begin{tabular}{|c|c|c|}
\hline Season & Months & Primary concern \\
\hline Winter & January-March & $\begin{array}{l}\text { Securing sufficient forage and } \\
\text { avoiding predation }\end{array}$ \\
\hline Spring & April-June & Parturition and calf survival \\
\hline Summer & July-September & Weaning of calves and mating \\
\hline Fall & October-December & $\begin{array}{l}\text { Rest and preparation for } \\
\text { winter }\end{array}$ \\
\hline
\end{tabular}

parameters were set to consider if associated females spent more than $70 \%$ of their time within $200 \mathrm{~m}$ of one another. The results indicated two associated females. One of the two was randomly removed. This resulted in 24 elk used for analysis; however, the number of individuals per season varied, ranging from 15 to 24 . The minimum number of locations per individual per season was 5 , but ranged up to 28.

The telemetry data points were overlain on digitized Ontario Base Map (OBM) and recent Forest Resource Inventory Map (FRI) habitat layers (2010), using GIS. This allowed each elk location to be linked to a stand-specific FRI attribute and forest classification category. The attributes used to classify habitat were polygon type (POLYTYPE) and forest type (FORTYPE), resulting in 14 available habitat types within the study area (Table 2). The minimum convex Polygon (MCP) of the telemetry locations for all individuals during all seasons and years was calculated and constituted the area that was considered as an available habitat. A conventional method used by Thomas and Taylor [44] and Schaefer et al. [45] was used to calculate the difference between percent habitat use and percent habitat available, and then a chi-squared test was performed for each habitat type. All statistics and some figures were performed using STATISTICA v. 8. Other figures were created using Excel. 
TABle 2: Description of habitat types used in habitat utilisation analyses (Forest Information Manual 2007, Ministry of Natural Resources).

\begin{tabular}{|c|c|}
\hline Code & Description (POLYTYPE) \\
\hline BSH & $\begin{array}{l}\text { Brush and alder: areas covered with "noncommercial" tree species or shrubs. These areas are normally } \\
\text { associated with wetlands or water features and must not be confused with productive forest areas of similar } \\
\text { brush or bush cover which have developed as a result of forest management operations (e.g., areas that have } \\
\text { been recently depleted or areas that are below silvicultural standards). }\end{array}$ \\
\hline DAL & $\begin{array}{l}\text { Developed agricultural land: lands which are cultivated for growing crops, orchards, floral gardens, and so } \\
\text { forth. These areas may include abandoned agricultural lands. }\end{array}$ \\
\hline GRS & $\begin{array}{l}\text { Grass and meadow: farm areas devoted to pasture for domesticated animals. These areas may also include } \\
\text { abandoned grass and meadows, but are not part of the productive forest land base and do not include "barren } \\
\text { and scattered" areas. These areas are similar to barren and scattered, but are located near developed agriculture } \\
\text { land or unclassified areas and are usually fenced. }\end{array}$ \\
\hline OMS & $\begin{array}{l}\text { Open wetland: wet areas of mosses, grasses, sedges, and small herbaceous plants, often interspersed with small } \\
\text { areas of open water. }\end{array}$ \\
\hline RCK & $\begin{array}{l}\text { Rock: areas of barren or exposed rock (e.g., bedrock, cliff face, and talus slope) which may support a few } \\
\text { scattered trees, but is less than } 25 \% \text { stocked. }\end{array}$ \\
\hline TMS & $\begin{array}{l}\text { Treed wetland: areas of dry or wet muskeg in which stunted trees occur as widely spaced individuals or in } \\
\text { small groups. }\end{array}$ \\
\hline UCL & $\begin{array}{l}\text { Unclassified: Nonforested areas which were created for specific uses other than timber production, such as } \\
\text { roads, railroads, logging camps, mines, utility corridors, logging camps, gravel pits, and airports. Most of these } \\
\text { areas have been cleared of trees. }\end{array}$ \\
\hline WAT & $\begin{array}{l}\text { All water areas: no designation (or polygon delineation) between lakes and wide rivers. Therefore, it includes } \\
\text { lakes, ponds, reservoirs (i.e., inland basin areas containing water), and wide (two-sided) rivers. These rivers are } \\
\text { natural or man-made bodies of flowing water, emptying into a stream, river, or lake. These are permanent } \\
\text { rivers or streams that can be defined by area (versus a line). Generally, these rivers/streams are consistently } \\
\text { wider than } 20 \text { meters when portrayed at a mapping scale of } 1: 10,000 \text { or consistently wider than } 40 \text { meters } \\
\text { when portrayed at a mapping scale of } 1: 20,000 \text {. Smaller/narrower rivers and streams are maintained as linear } \\
\text { features in a centerline layer(s). }\end{array}$ \\
\hline FOR & $\begin{array}{l}\text { Forest: areas that are capable of producing trees and can support tree growth. These areas may or may not be } \\
\text { capable of supporting the harvesting of timber on a sustained yield basis. Some areas may have physical and/or } \\
\text { biological characteristics which affect land use. Thus, this polygon type includes both production and } \\
\text { protection forest areas. }\end{array}$ \\
\hline Code & Description (FORTYPE) \\
\hline CONIF LOW & Lowland conifers: predominantly black spruce stands on low, poorly drained sites. \\
\hline CONIF UP & Upland conifers: predominantly mixed spruce, jack pine and fir stands on upland sites. \\
\hline GL-SL PINES & $\begin{array}{l}\text { Great Lakes-St. Lawrence Pines: white and red pine dominated stands, often mixedwood with overstory of } \\
\text { white pine, and a lower canopy of other tree species including poplar, spruce and hardwoods. Most commonly } \\
\text { found in the Great Lakes-St. Lawrence Forest Region and Boreal transitional forests. }\end{array}$ \\
\hline INTOL HARDWOOD & Intolerant hardwood: Trembling aspen, white birch, and balsam poplar. \\
\hline TOL HARDWOOD & $\begin{array}{l}\text { Tolerant hardwood: generally maple, with a lesser component of yellow birch, oak, beech, basswood, elm, and } \\
\text { ash. Dominant forest type in the Great Lakes-St. Lawrence Forest Region. }\end{array}$ \\
\hline UP MIXED & Upland mixed: mixed stands made up mostly of spruce, jack pine, fir, poplar, and white birch. \\
\hline
\end{tabular}

\section{Results}

The comparison of $\%$ habitat use to \% habitat available showed significant selection for intolerant hardwood forest (INTOL HARDWOOD) (trembling aspen, white birch, and balsam poplar) during all seasons. Elk used the Great LakesSt. Lawrence Pine habitat (white and red pine dominated stands) less than expected based on availability for all seasons (Figures 2 and 3). Upland mixed forest (UP MIXED) (mixed stands made up of mostly spruce, jack pine, poplar, and white birch) was also selected in winter only (Figure $2(\mathrm{~d})$ ).

\section{Discussion}

We found that intolerant hardwoods were selected during all seasons and Great Lakes-St. Lawrence Pines were used significantly less than expected for all seasons. Martin [9], Brown [32], and Jost [33] found similar results both for the remnant (elk reintroduced in 1930s and 1940s) and the newly reintroduced Burwash elk.

Brown [32] found that elk comprising the remnant population selected forest stands containing poplar, white birch, white spruce (Picea glauca), and balsam fir (Abies balsamea), 


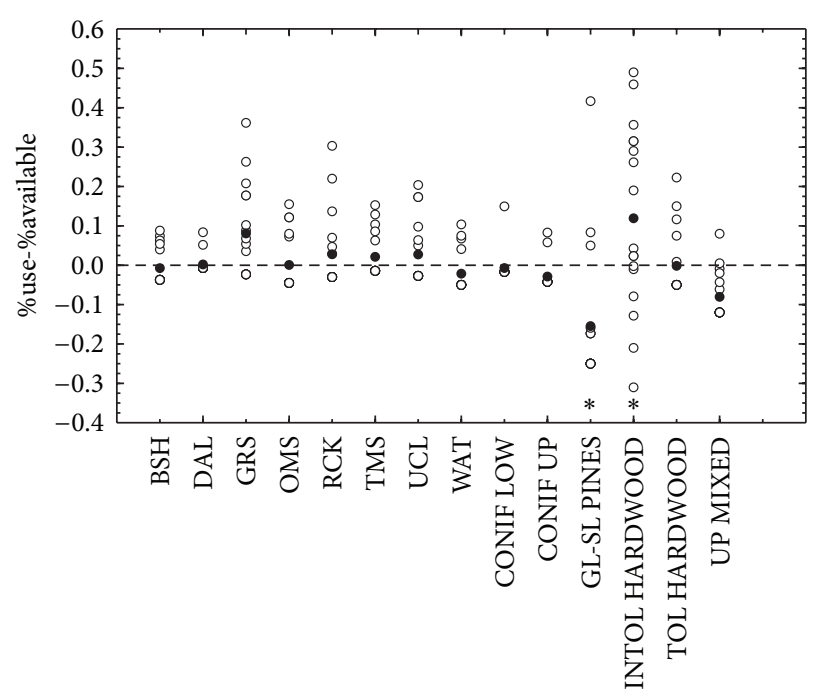

(a)

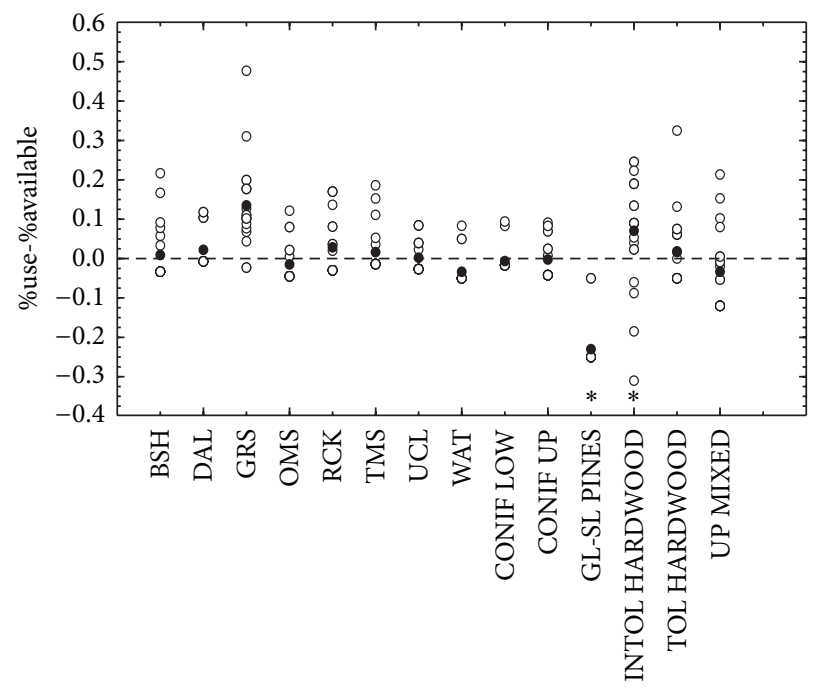

(c)

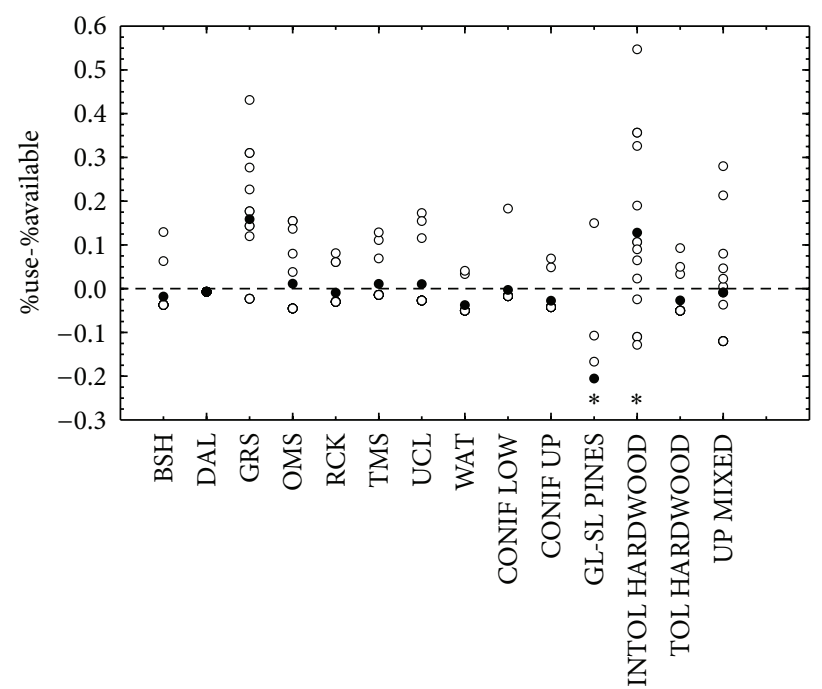

(b)

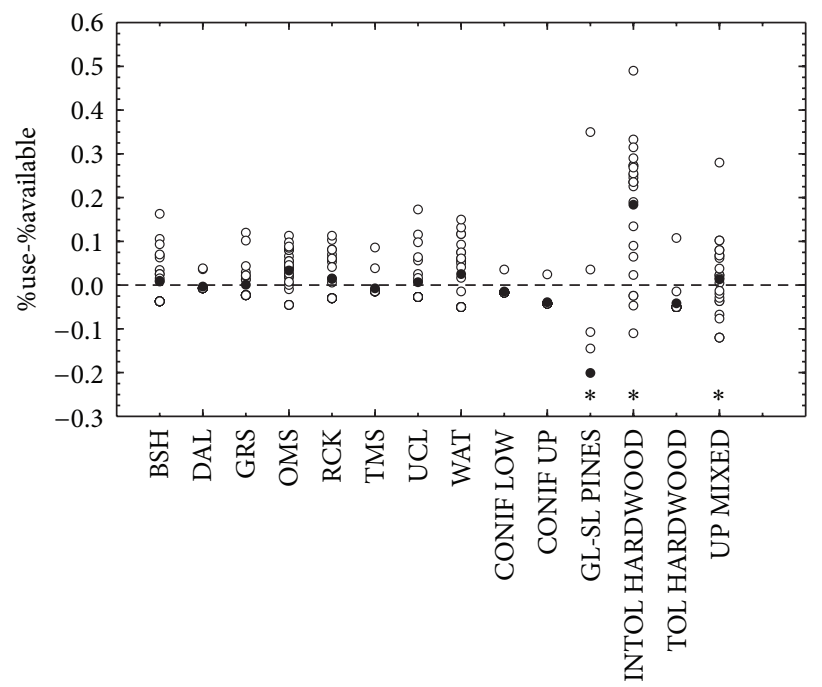

(d)

FIGURE 2: Comparison of \% use by study elk to \% availability for 14 habitat types during spring (a), summer (b), fall (c), and winter (d). Each hollow datum represents one animal; filled datum represents means. Means significantly different from zero are indicated by ${ }^{*}(P \leq 0.01)$ Note: there may be overlap in data points due to grouping of individuals.

as well as rock outcrops and black spruce (Picea mariana)white pine (Pinus strobus) stands. The black spruce-white pine stands were selected during autumn and winter, a behaviour also recognized by Peck and Peek [46] in a British Columbia elk population. Conifer-dominated stands have been selected by elk in many other studies in Western North America $[15,34,35,47,48]$ as well as in Europe $[49,50]$. We found that upland mixed forest of spruce, jack pine, poplar, and white birch was selected only in winter. The selection of conifer-dominated stands may be attributed to changes in forage availability in relation to snow accumulation [46, 51]. Snow depth can have a large impact on the availability and utilization of elk forage, sometimes causing a shift in diet from forbs and graminoids to woody browse, as previously shown by the remnant elk in Burwash [33]. Intolerant hardwood forest types were the main forest type selected by elk in our study, while elk used conifer-dominated stands (GL-SL PINES) much less than expected.

Deciduous forest types have also been shown to be selected by elk [23, 25, 48, 52]. Although weather patterns were not recorded in our study or in Brown's [32] study, the apparent difference in the selection of conifer stands over intolerant hardwoods may be attributed to varying degrees of winter severity and snow depth between the two studies. Another plausible cause for the difference could be sample size, as Brown [32] studied a rather limited number of elk $(n<10)$.

Elk have also been shown to cope with winters of deep snow by utilizing south to west facing slopes [35]. In Burwash, elk selected high elevation ridges, likely due to the lower 


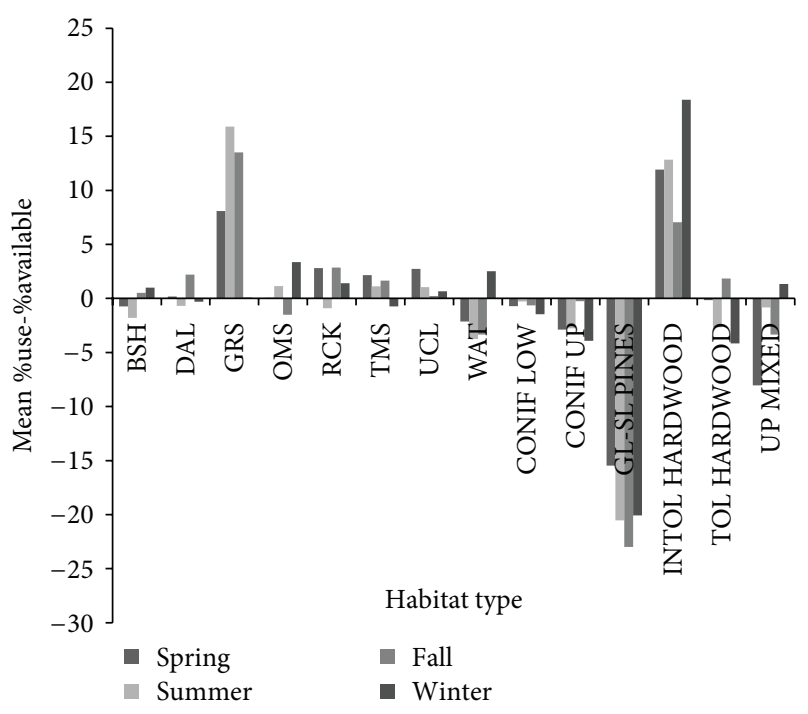

FIgURE 3: The mean differences between $\%$ use and $\%$ available for each habitat type in different seasons.

depth and higher density of snow, caused by the sweeping action of wind and providing increased elk mobility [30, 32, 33, 41]. Jost [33] found that increased snow depth resulted in the use of woody browse in mixed forest habitats by the remnant Burwash elk herd in early spring.

Jost [33] also found that resident Burwash elk utilized intolerant hardwood tree species (trembling aspen, white birch, and balsam poplar). In her study, GL-SL PINES (red and white pines) were not used as forage and were not preferred. Mixed forest habitat held the greatest importance, because the majority of preferred forage items were found in it. The most common elk forage items in Burwash were common hairgrass (Deschampsia flexuosa), large-leaved aster (Aster macrophyllus), red maple (Acer rubrum), blue bead lily (Clintonia borealis), white birch (Betula papyrifera), willows (Salix spp.), red oak (Quercus rubra), beaked hazel (Corylus cornuta), evening primrose (Oenothera biennis), and trembling aspen (Populus tremuloides) [33], all of which fall within forage classes utilized by Western North American elk [31].

Martin [9] showed that after elk became acclimatized after reintroduction, they selected intolerant hardwoods and upland mixed forests. Other elk populations introduced in Ontario have shown habitat selection patterns similar to the Burwash population. Elk introduced into North-Western Ontario selected poplar-dominated habitats [53]. In eastern Ontario, elk browsed trembling aspen, choke cherry, and white birch in open, shade-intolerant deciduous habitats [54].

Brown [32] found that the remnant Burwash elk avoided grass/meadow habitats, contradicting the present and Western North American studies, which have indicated elk selection of this habitat type $[18,46,55]$. Elk in British Columbia wintered primarily on young postburn vegetation dominated by grass and shrubs, with the exception of severe winters, when they utilized conifer stands [46]. Jost [33] found that in summer, forb species found in shaded forests, as opposed to open grasslands, were most important to elk. Grasslands also produce a number of elk forage items and were used more than other habitats in spring. This was likely due to early initiation of leaf growth on trees and shrubs which occurs in open areas [35]. In addition to grasslands, elk also continue to use shrub and open timber habitats in spring, summer, and fall [35]. Elk have been associated with openings of all types including abandoned farm fields or lumber camps, orchards, and air strips, where new forage is available and cover is close by [56]. Along with using open habitats as travel corridors, elk may prefer them in spring due to the early appearance of preferred forage species [39]. Although elk have been known to select open areas in other regions, in our study, elk did not show a selection for grass/meadow habitats.

\section{Conclusions}

The most prominent habitat selection patterns displayed by the Burwash elk population in Ontario were selection for intolerant hardwoods during all seasons and the selection of upland mixed forests in winter. Because the habitat selection of elk varies greatly between populations, it is recommended that managers consider population-specific habitat selection prior to making related management decisions. Because habitat selection may vary with scale [29], time of day [56], and changes in weather patterns $[35,46]$, it is also recommended that these variables be included in future studies of habitat selection by the Burwash elk population as well as in other elk populations.

\section{Acknowledgment}

The authors would like to thank the Sudbury Elk Restoration Committee (SERC) for the financial support.

\section{References}

[1] O. Murie, The Elk of North America, Stackpole Company, Harrisburg, Pa, USA, 1951.

[2] L. Bryant and C. Maser, "Classification and distribution," in North American Elk: Ecology and Management, J. W. Thomas and D. Toweill, Eds., pp. 1-60, Stakepole Books, Harrisburg, Pa, USA, 1982.

[3] J. Peek, "Wapiti (Cervus elaphus)," in Wild Mammals of North America, Biology, Management and Conservation, G. Feldhamer, B. Thompson, and J. Chapman, Eds., pp. 877-905, The Johns Hopkins University Press, Baltimore, Md, USA, 2003.

[4] B. O'Gara and R. Dundas, "Distribution: past and present," in American Elk, Ecology and Management, D. Toweill and J. W. Thomas, Eds., pp. 67-119, North Smithsonian Institution Press, Washington, DC, USA, 2002.

[5] R. Rosatte, J. Hamr, B. Ranta, J. Young, and N. Cool, "Elk restoration in Ontario, Canada: infectious disease management strategy, 1998-2001," Annals of the New York Academy of Sciences, vol. 969, pp. 358-363, 2002.

[6] J. Larkin, D. Maehr, J. Cox, D. Bolin, and M. Wichrowski, "Demographic characteristics of a reintroduced elk population in Kentucky," Journal of Wildife Management, vol. 67, no. 3, pp. 467-476, 2003. 
[7] J. L. Larkin, J. J. Cox, M. R. Dzialak, M. W. Wichrowski, and D. S. Maehr, "Influences on release-site fidelity of translocated elk," Restoration Ecology, vol. 12, no. 1, pp. 97-105, 2004.

[8] R. Rosatte, J. Hamr, J. Young, I. Filion, and H. Smith, "The restoration of elk (Cervus elaphus) in Ontario, Canada: 19982005," Restoration Ecology, vol. 15, no. 1, pp. 34-43, 2007.

[9] M. M. Martin, Spatial behaviour and habitat use by elk (Cervus elaphus) in response to highway construction and interprovincial relocation [M.S. thesis], Department of Biology, Laurentian University, Sudbury, Canada, 2011.

[10] M. S. Boyce, The Jackson Elk Herd: Intensive Wildlife Management in North America, Cambridge University, Cambridge, UK, 1989.

[11] E. H. Merril and M. S. Boyce, "Summer range and elk population dynamics in Yellowstone National Park," in The Greater Yellowstone Ecosystem, R. B. Keiter and M. S. Boyce, Eds., pp. 263-273, Yale University, New Haven, Conn, USA, 1991.

[12] M. Turner, Y. Wu, L. L. Wallace, W. H. Romme, and A. Brenkert, "Simulating winter interactions among ungulates, vegetation, and fire in Northern Yellowstone Park," Ecological Applications, vol. 4, no. 3, pp. 472-496, 1994.

[13] S. M. Pearson, M. G. Turner, L. L. Wallace, and W. H. Romme, "Winter habitat use by large ungulates following fire in Northern Yellowstone National Park," Ecological Applications, vol. 5, no. 3, pp. 744-755, 1995.

[14] L. L. Wallace, M. G. Turner, W. H. Romme, R. V. O’Neill, and Y. $\mathrm{G}$. Wu, "Scale of heterogeneity of forage production and winter foraging by elk and bison," Landscape Ecology, vol. 10, no. 2, pp. 75-83, 1995.

[15] M. S. Boyce, J. S. Mao, E. H. Merrill et al., "Scale and heterogeneity in habitat selection by elk in Yellowstone National Park," Ecoscience, vol. 10, no. 4, pp. 421-431, 2003.

[16] S. M. McCorquodale, "Sex-specific movements and habitat use by elk in the cascade range of Washington," Journal of Wildife Management, vol. 67, no. 4, pp. 729-741, 2003.

[17] J. M. Skovlin, "Habitat requirements and evaluations," in Elk of North America: Ecology and Management, J. W. Thomas and D. E. Toweill, Eds., pp. 369-413, Stackpole Books, Harrisburg, Pa, USA, 1982.

[18] W. B. Collins and P. J. Urness, "Feeding behavior and habitat selection of mule deer and elk on Northern Utah summer range," Journal of Wildlife Management, vol. 47, no. 3, pp. 646663, 1983.

[19] K. E. Grover and M. J. Thompson, "Factors influencing spring feeding site selection by elk in the Elkhorn Mountains, Montana," Journal of Wildlife Management, vol. 50, no. 3, pp. 466470, 1986.

[20] M. L. Rosenzweig, "Habitat selection, community organization, and small mammal studies," in Patterns in the Structures of Mammalian Communities, D. W. Morris, Z. Abramsky, B. J. Fox, and M. R. Texas, Eds., pp. 5-21, Tech University Press, Lubbock, Tex, USA, 1989.

[21] P. D. McLoughlin, M. S. Boyce, T. Coulson, and T. CluttonBrock, "Lifetime reproductive success and density-dependent, multi-variable resource selection," Proceedings of the Royal Society B, vol. 273, no. 1593, pp. 1449-1454, 2006.

[22] G. W. Witmer and D. S. Decalesta, "Habitat use by female roosevelt elk Cervus-elaphus-roosevelti in the Oregon USA Coast Range," Journal of Wildlife Management, vol. 47, no. 4, pp. 933-939, 1983.
[23] B. Bobek, M. S. Boyce, and M. Kosobucka, "Factors affecting red deer Cervus elaphus population density in Southeastern Poland," Journal of Applied Ecology, vol. 21, no. 3, pp. 881-890, 1984.

[24] A. A. Ager, B. K. Johnson, J. W. Kern, and J. G. Kie, "Daily and seasonal movements and habitat use by female Rocky Mountain elk and mule deer," Journal of Mammalogy, vol. 84, no. 3, pp. 1076-1088, 2003.

[25] G. L. Schroer, K. J. Jenkins, and B. B. Moorhead, "Roosevelt elk selection of temperate rain forest seral stages in Western Washington," Northwest Science, vol. 67, no. 1, pp. 23-29, 1993.

[26] J. M. Vore, T. L. Hartman, and A. K. Wood, "Elk habitat selection and winter range vegetation management in Northwest Montana," Intermountain Journal of Sciences, vol. 13, pp. 86-97, 2007.

[27] M. Zhang, Z. Liu, and L. Teng, "Seasonal habitat selection of the red deer (Cervus elaphus alxaicus) in the Helan Mountains, China," Zoologia (Curitiba), vol. 30, pp. 24-34, 2013.

[28] D. P. Anderson, M. G. Turner, J. D. Forester et al., "Scaledependent summer resource selection by reintroduced elk in Wisconsin, USA," Journal of Wildlife Management, vol. 69, pp. 298-310, 2005.

[29] D. H. Johnson, "The comparison of usage and availability measurements for evaluating resource preference," Ecology, vol. 61, pp. 65-71, 1980.

[30] A. M. Kittle, J. M. Fryxell, J. E. Desy, and J. Hamr, "The scaledependent impact of wolf predation risk on resource selection by three sympatric ungulates," Oecologia, vol. 157, no. 1, pp. 163$175,2008$.

[31] M. Jost, J. Hamr, I. Filion, and F. F. Mallory, "Forage selection by elk in habitats common to the French River-Burwash region of Ontario," Canadian Journal of Zoology, vol. 77, no. 9, pp. 14291438, 1999.

[32] G. S. Brown, Spatial behaviour and habitat utilzation of Wapiti (Cervus elaphus) in the French River and Burwash Regions of Ontario [M.S. thesis], Department of Biology, Laurentian University, Sudbury, Canada, 1998.

[33] M. A. Jost, Forage utilization by Wapiti (Cervus elaphus) in the French River and Burwash Regions of Ontario [M.S. thesis], Department of Biology, Laurentian University, Sudbury, Canada, 1997.

[34] L. L. Irwin and J. M. Peek, "Elk habitat use relative to forest succession in Idaho," Journal of Wildlife Management, vol. 47, no. 3, pp. 664-672, 1983.

[35] J. W. Unsworth, L. Kuck, E. O. Garton, and B. R. Butterfield, "Elk habitat selection on the Clearwater National Forest, Idaho," Journal of Wildlife Management, vol. 62, no. 4, pp. 1255-1263, 1998.

[36] J. S. Mao, M. S. Boyce, D. W. Smith et al., "Habitat selection by elk before and after wolf reintroduction in Yellowstone National Park," Journal of Wildlife Management, vol. 69, no. 4, pp. 16911707, 2005.

[37] J. S. Rowe, Forest Regions of Canada, Canadian Forest Service, Ottawa, Canada, 1972.

[38] B. K. Chambers, K. Legasy, and C. V. Bentley, Forest Plants of Central Ontario, Lone Pine Publishing, Edmonton, Canada, 1996.

[39] J. L. Vankat, The Natural Vegetation of North America: An Introduction, John Wiley \& Sons, Toronto, Canada, 1979.

[40] M. M. Dillon, Burwash Land Use Study. 8182-01, Ministry of Government Services, 1978. 
[41] B. Ranta, Range and habitat relationships of Wapiti (Cervus canadensis) in the Burwash-French River area of Ontario [M.S. thesis], Carleton University, Ottawa, Canada, 1979.

[42] G. C. White and R. A. Garrott, Analysis of Wildlife RadioTracking Data, Academic Press, San Diego, Calif, USA, 1990.

[43] K. T. Weber, M. Burcham, and C. L. Marcum, "Assessing independence of animal locations with association matrices," Journal of Range Management, vol. 54, no. 1, pp. 21-24, 2001.

[44] D. L. Thomas and E. J. Taylor, "Study designs and tests for comparing resource use and availability," Journal of Wildlife Management, vol. 54, no. 2, pp. 322-330, 1990.

[45] J. A. Schaefer, N. Morellet, D. Pépin, and H. Verheyden, "The spatial scale of habitat selection by red deer," Canadian Journal of Zoology, vol. 86, no. 12, pp. 1337-1345, 2008.

[46] V. R. Peck and J. M. Peek, "Elk, Cervus elaphus, habitat use related to prescribed fire, Tuchodi River, British Columbia," Canadian Field-Naturalist, vol. 105, pp. 354-362, 1991.

[47] M. A. Rumble and R. S. Gamo, "Habitat use by elk (Cervus elaphus) within structural stages of a managed forest of the northcentral United States," Forest Ecology and Management, vol. 261, no. 6, pp. 958-964, 2011.

[48] I. M. R. Godvik, L. E. Loe, J. O. Vik, V. Veiberg, R. Langvatn, and A. Mysterud, "Temporal scales, trade-offs, and functional responses in red deer habitat selection," Ecology, vol. 90, no. 3, pp. 699-710, 2009.

[49] Z. Bíró, L. Szemethy, K. Katona, M. Heltai, and Z. Petö, "Seasonal distribution of red deer (Cervus elaphus) in a forestagriculture habitat in Hungary," Mammalia, vol. 70, no. 1-2, pp. 70-75, 2006.

[50] A. M. Licoppe and S. A. de Crombrugghe, "Assessment of spring habitat selection of red deer (Cervus elaphus L.) based on census data," Zeitschrift fur Jagdwissenschaft, vol. 49, no. 1, pp. 1-13, 2003.

[51] R. R. Knight, “The Sun River elk herd," Wildlife Monographs, vol. 23, pp. 1-66, 1970.

[52] G. Jiang, M. Zhang, and J. Ma, "Habitat use and separation between red deer Cervus elaphus xanthopygus and roe deer Capreolus pygargus bedfordi in relation to human disturbance in the Wandashan Mountains, Northeastern China," Wildlife Biology, vol. 14, no. 1, pp. 92-100, 2008.

[53] T. E. McIntosh, Movements, survival and habitat use by elk (Cervus elaphus) reintroduced to Northwestern Ontario [M.S. thesis], Lakehead University, Thunder Bay, Canada, 2003.

[54] D. A. Jenkins, J. A. Schaefer, R. Rosatte, T. Bellhouse, J. Hamr, and F. F. Mallory, "Winter resource selection of reintroduced elk and sympatric white-tailed deer at multiple spatial scales," Journal of Mammalogy, vol. 88, no. 3, pp. 614-624, 2007.

[55] A. P. Wydeven and R. B. Dahlgren, "Ungulate habitat relationships in Wind Cave National Park," Journal of Wildlife Management, vol. 49, no. 3, pp. 805-813, 1985.

[56] J. J. Millsapugh and J. M. Marzluff, Radio Tracking and Animal Populations, Acadmenic Press, San Diego, Calif, USA, 2001. 

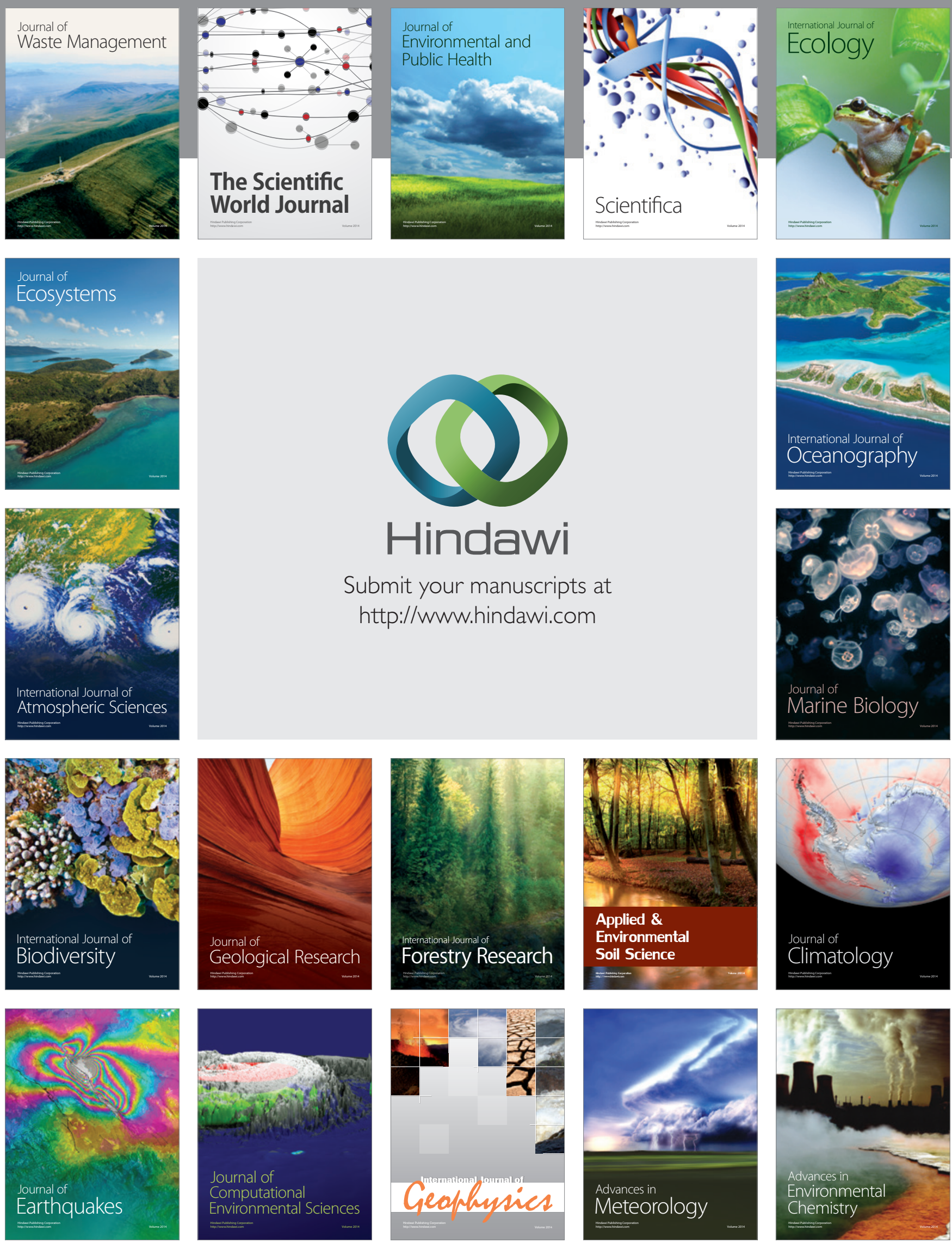